\title{
PERJALANAN AVEROISME KE EROPA DAN PENGARUHNYA TERHADAP PERKEMBANGAN DUNIA MODEREN
}

\author{
Afrizal $M$
}

\begin{abstract}
Averroism developed in Europe through translation of Ibn Rushd's works by his Jewish disciples. Averroism concept that the Europeans were very interested was that between religion and philosophy are not contradictive. Therefore, conflict between religionist and scientist might not occur. The entrance of Averroism to Europe brought about enlightenment in the West. Averroism's ideas opened the Western thought horizon about their underdevelopment in scientific field. This yet caused them to master the most progressive sciences until nowadays.
\end{abstract}

Keywords : Averroism, renaissance, and Europe development.

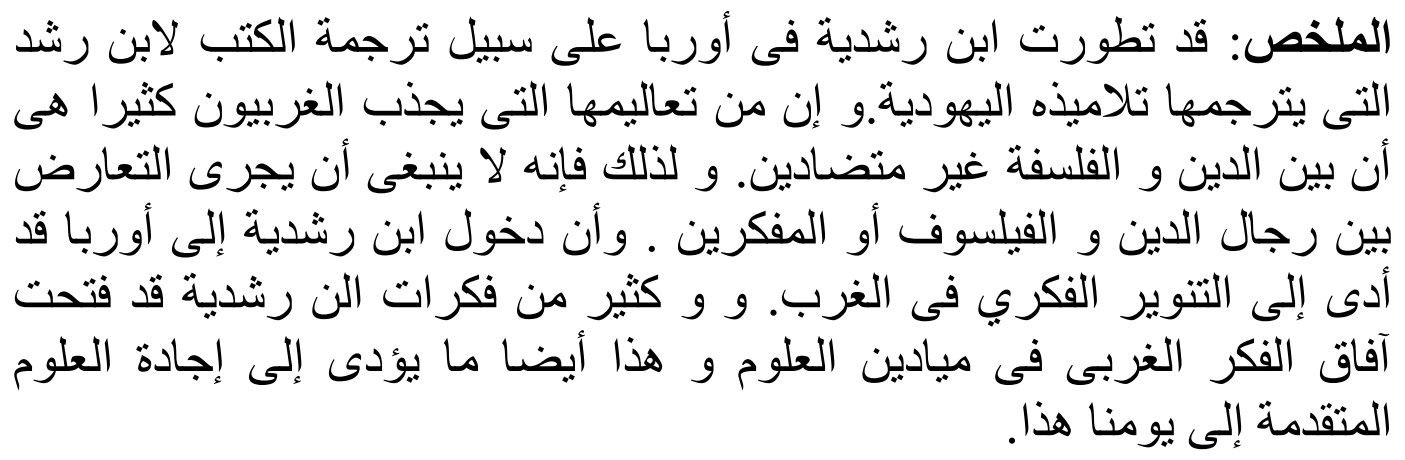

\section{Pendahuluan}

Averroes adalah nama lain dari Ibn Rusyd. Averroes terkenal di dunia Barat, sementara Ibn Rusyd terkenal di dunia Islam. Ada kemungkinan para pemikir Barat tidak mau memakai nama Ibn Rusyd karena pemakaian nama memang tidak dikenal di Barat, sementara yang sesuai dengan lisan mereka adalah Averroes. ${ }^{1}$ Ibn Rusyd lahir di Cordova pada tahun 520 H/ 1126 M. Ia berasal dari keluarga yang ahli dalam ilmu fikih. Kakek Ibn Rusyd adalah seorang ahli fikih yang berpandangan luas dan pernah menjabat qadi al-qudah, setingkat jaksa Agung di zaman kita. ${ }^{2}$

Lingkungan ilmuan ini sangat berpengaruh bagi pertumbuhan Ibn Rusyd. Ibn Rusyd menjadi ilmuan setara dengan ilmuan-ilmuan lain di dunia. Ia juga menguasai fikih sehingga sampai saat kita dapat membaca kitab Bidayah alMujtahid tulisan Ibn Rusyd. Kitab ini mengemukakan pikiran-pikiran imam mujtahid, bukan hanya mengemukakan satu mazhab saja. Tetapi berbeda dengan orang tuanya, Ibn Rusyd lebih terkenal dalam filsafat ketimbang fikih. Di dunia Islam namanya terkenal setelah melancarkan kritik terhadap buku Tahafut al-Falasifah karya al-Gazali. Selain itu pikirannya tentang keselarasan agama dan filsafat menambah harum namanya di Barat melampaui dunia Islam. Pikirannya inilah yang dikemukakan dalam tulisan ini. 


\section{Hubungan Dunia Islam dan Eropa}

Kontak pertama Eropa dengan dunia Islam dimulai dengan diterjemahkannya buku-buku filsafat oleh al-Kindi, al-Farabi dan Ibn Sina 11301150. Penerjemahan ini dipelopori Rymon Castel, Uskup Toledo ketika Ibn Rusyd berumur 4 tahun. ${ }^{3}$ Dan kontak kedua terjadi setelah Ibn Rusyd melahirkan pikiran-pikirannya. Kontak tersebut bermula dari sikap Abu Yusuf al-Mansur, putra Abu Ya`qub, yang menerima fitnah dari orang-orang yang tidak menyukai Ibn Rusyd. Akibat fitnah itu Ibn Rusyd dicurigai, ditangkap dan diasingkan ke Lucena di Selatan Cordova. Lebih dari itu khalifah memerintahkan agar semua buku Ibn Rusyd dilarang untuk dibaca dan dibakar. ${ }^{4}$

Ada pendapat yang mengatakan bahwa di antara sebab fitnah itu ialah keinginan para Fuqahak untuk mendapat kedudukan yang tinggi di sisi khalifah. Dalam sejarah Islam Andalusia para ahli fikih telah lama mendapat kedudukan yang tinggi terutama pada masa pemerintahan Dinasti Murabitun. ${ }^{5}$ Karena itu mereka ingin kembali meraih jabatan itu. Dalam hal ini Ernest Renan (1957) menanggapi lain, Pemerintahan Muwahhidun terdiri atas pengikut Imam alGazali yang anti filsafat dan pendirinya adalah Ibn Tumart, seorang murid alGazali yang setia. ${ }^{6}$ Akan tetapi dalam konteks ini Mahmud Qasim membantah bahwa fitnah itu tidak tepat karena pendapat itu ditulis Ibn Rusyd dalam buku "al-Kasyf an Manahij al-Adillah pada tahun 575 H. Dalam buku tersebut Ibn Rusyd mengritik ulama-ulama kalam, baik pengikut al-Asy’ari maupun pengikut lainnya, sedangkan fitnah itu terjadi 16 tahun setelah buku itu ditulisnya. ${ }^{7}$

Fitnah ini disebarluaskan dengan mengatakan bahwa Ibn Rusyd sudah murtad dan menentang kepercayaan yang dianut umat Islam. Dalih yang dikemukakan adalah dengan mengatakan Ibn Rusyd mengagungkan filsafat Yunani yang menurut mereka bertentangan dengan ajaran Islam. Oleh sebab itu, Ibn Rusyd telah sesat, menyesatkan orang-orang Islam lain, tidak sopan dan menghina khalifah sebagai kepala negara. ${ }^{8}$

Pembuangan Ibn Rusyd ke Lucena tidak berlangsung lama, hanya satu tahun. Setelah itu khalifah menyesali perbuatannya yang tidak menghormati ilmuan. Setelah kembali ke Maroko dari lawatan ke daerah-daerah khalifah mencabut kembali instruksi umum yang disebarkannya mengenai Ibn Rusyd. ${ }^{9}$ Adapun sebab-sebab penarikan kembali instruksi itu kurang jelas.

Anehnya, ketika pembuangan ke Lucena dan buku-bukunya dibakar, pengaruh Ibn Rusyd bukan hilang, melainkan semakin marak. Beberapa orang muridnya yang setia antara lain Maimunides dan Josef bin Jehovah, keduanya berkebangsaan Yahudi, menyambutnya dengan rasa kecintaan. Di masa pembuangan itu Ibn Rusyd meneruskan pekerjaannya mengajar dan menulis sehingga banyak sekali pemuda Yahudi yang belajar kepadanya. ${ }^{10}$ Oleh sebab itu, tidaklah mengherankan, walaupun buku-buku Ibn Rusyd dalam bahasa Arab telah dibakar habis, buku-bukunya yang diterjemahkan ke dalam Bahasa Yahudi tetap dijumpai atas prakarsa murid-muridnya ketika Ibn Rusy berada di pembuangan. Dan mungkin juga setelah itu khalifah mengampuni Ibn Rusyd, sehingga buku-buku itu ditulis kembali. 
Selain dibakar oleh Khalifah al-Mansur, Ximenez Archbishop, warga Jerman yang sangat fanatik dan biadab dalam memperjuangkan kemenangan Kristen dalam rangka menumbangkan pemerintahan al-Muwahhidun juga telah memerintahkan untuk membakar buku-buku Arab di Andalusia. Tujuan mereka adalah untuk menghapus peradaban Islam. ${ }^{11}$ Dengan ini pastilah bukubuku Ibn Rusyd (dalam Bahasa Arab) habis musnah karena fanatik membabibutanya orang-orang Eropa.

Walaupun karya-karya Ibn Rusyd dalam bahasa aslinya sudah musnah dalam beberapa kali pembakaran, tetapi anehnya buku-buku itu tersiar dalam waktu yang dekat di berbagai tempat di Eropa yang ditulis dalam bahasa Latin dan Hebrew (Yahudi). ${ }^{12}$ Kalau Renan dapat dipercaya, tanpa bantuan orangorang Yahudi tulisan-tulisan Averous tidak akan dikenal dunia sekarang. Naskah-naskahnya dalam bahasa Arab sulit sekali kita peroleh. Kebanyakan naskah Ibn Rusyd yang diterjemahkan ke dalam bahasa Latin diambil dari naskah-naskah bahasa Ibrani. Kabarnya, juga kalau laporan Renan benar ada 80.000 buku Ibn Rusyd yang dibakar di Granada. Boleh jadi angka itu berlebihan. Tetapi buku-buku Ibn Rusyd memang tidak begitu populer di dunia Islam.

Sikap-sikap mahasiswa Cordova yang datang dari berbagai penjuru Eropa telah berusaha menyelamatkan sebagian buku Ibn Rusyd, lalu diangkut ke Toledo yang ketika itu menjadi pusat penerjemahan. Ahli-ahli penerjemah seperti Rahib Jiral Paus Salfaster menerjemahkan 80 buah buku-buku Arab ke bahasa latin..$^{13}$ Musa ibn Maimun, seorang reformis Yahudi, pada tahun $1191 \mathrm{M}$, yakni sebelum wafat Ibn Rusyd, telah terpengaruh pada buku-buku Ibn Rusyd dan menulis buku "Dilalah al-Haizin" yang argumennya diambil dari Ibn Rusyd. ${ }^{14}$

Penerjemahan berikutnya terjadi pada tahun $1230 \mathrm{M}$. Di antara penerjemah yang terkenal adalah Michael Scott yang menerjemahkan buku-buku Ibn Rusyd, terutama buku-buku filsafat seperti buku Syarh Kitab al-Sama' wa al-Ard", buku "Syarh Kitab al-Nafs". Terjemahan ini dihadiahkan kepada Fredrick II, Raja Jerman yang tinggal di Balram. Pada tahun 1256, Herman dari Jerman menerjemahkan buku "Syarh Ibn Rusyd li Kitab al-Syi r li Aristo"15. Atas jasa-jasa penerjemahan inilah buku-buku Ibn Rusyd menjadi berpengaruh bagi masyarakat Eropa.

Pengaruh Ibn Rusyd ini telah terlihat pada waktu pemuda-pemuda Eropa belajar ke Andalusia yakni di Universitas Cordova, Universitas Seville, Malaga, dan Granada. Dari universitas-universitas tersebut para mahasiswa itu mengenal pemikiran Ibn Rusyd. Setelah Ibn Rusyd wafat, Eropa mulai meniru langkah Andalusia mendirikan universitas dan sekolah-sekolah lainnya. Sejarah menyebutkan bahwa universitas pertama di Eropa adalah Universitas Paris yang didirikan pada tahun $1231 \mathrm{M}$, lebih kurang 30 tahun setelah Ibn Rusyd meninggal. Setelah berakhirnya periode abad pertengahan, yaitu setelah beberapa ratus tahun barulah Eropa mempunyai 18 buah universitas. ${ }^{16}$ Ilmuilmu pengetahuan yang dipelajari di universitas-universitas itu antara lain ilmu kedokteran, ilmu pasti, filsafat dan sebagainya, semua itu bersumber dari pemikir-pemikir Muslim. Khusus mengenai filsafat yang dipelajari antara lain pemikiran al-Afarabi., Ibn Sina dan Ibn Rusyd serta komentarnya terhadap Aristoteles. ${ }^{17}$ 


\section{Sikap Eropa terhadap Pemikiran Ibn Rusyd}

Suasana Eropa pada abad ke 13 dan abad-abad selanjutnya terbagi kepada dua kelompok: Pertama kelompok yang menentang pemikiran Ibn Rusyd, yaitu golongan gereja. Kedua kelompok yang menyokong pemikiran Ibn Rusyd yang disebut oleh Gereja sebagai ilhad atau atheis. Eropa ketika itu berada dalam pertarungan antara kelompok penentang dan kelompok pendukung itu. ${ }^{18}$

Sebelum pemikiran Ibn Rusyd masuk ke Eropa sebenarnya golongan yang dikategorikan sebagai ilhad itu telah muncul. Di Padua misalnya marsilius, tokoh abad reformasi kehilangan hormatnya pada gereja. Di sini filosof Algeri da Nola, pendahulu Giardano Bruno menyerap penemuan baru dan disiarkan kepada masyarakat umum sehingga menyebabkan ia harus mengakhiri hidupnya dalam air mendidih. Pada tahun 1492 Agustiono Nifo menulis "De intelectu et Daemonibus yang menegaskan doktrin imortalitas jiwa dunia (world soul), salah satu tonggak Averoisme. Ia menghindari inkuisisi dengan mengemukakan "teori dua kebenaran, (juga dari Averois), kebenaran agama dan kebenaran filsafat.

Ini juga akibat dari pemiikiran Averroes tentang ta`wil al-Quran yang menyatakan adanya dua macam pemahaman terhadap al-Quran, yaitu untuk awam dan untuk filosof. Nifo juga berkata "Lequendum est at plures sentienduk ut pauci. Kita harus berbicara seperti kebanyakan orang tetapi harus berfikir seperti sedikit orang.

Pada abad ke $8 \mathrm{M}$ telah ada kelompok yang menyebabkan aliran batiniah ilhadiah. Mereka mengingkari alam diciptakan (khalq) hari kebangkitan dan kekekalan al-nafs. Selanjutnya ketika filsafat Aristoteles dibawa ke Eropa mereka (golongan ilhad) menggunakan filsafat itu sebagai senjata untuk menentang Gereja. Kemudian diikuti pula dengan kesibukan pembicaraan mengenai filsafat Ibn Rusyd pada abad 13, mereka dengan segera menamakan dirinya "al-Rasyidun al-Latiniyyun. ${ }^{19}$

Menurut tradisi, Gereja ingin menjaga akidah mereka dari pengaruh gerakan ilhad. Kelompok Gereja tidak mau pengikutnya menjadi sesat. Sejalan dengan itu muncul pula kelompok Dominican yang menganalisa filsafat Ibn Rusyd dengan ketua Siger de Van Braban yang menyokong Ibn Rusyd. ${ }^{20}$ Disisi lain Thomas Aquinas ${ }^{21}$ tampil sebagai penantang Brabant. Pada tahun $1215 \mathrm{M}$ Gereja mengeluarkan larangan tentang "haram membaca buku-buku Aristoteles, antara lain buku "Ma wara al-Tabi ah dan buku al-Falsafah al-Tabi 'ah", serta bukubuku ringkasan dan komentarnya dari Ibn Rusyd. Hal itu membuktikan betapa hebatnya pengaruh pemikiran Ibn Rusyd di Eropa pada masa itu.

\section{Averroisme di Eropa}

Apakah sebabnya pemikiran Ibn Rusyd berkembang di Eropa pada abad ke 13 yang akhirnya menjadi faktor utama pada kebangkitan Eropa. Gustave Lebon, seorang ahli ilmu kemasyarakatan berkata: "Tidak ada seorang Eropa pun hingga abad ke 15 melainkan ilmunya ditimba dari ilmuan Arab". Ahli-ahli ilmu pengetahuan Eropa mengatakan bahwa sesungguhya mereka menjadi murid dari orang-orang Islam (Arab). Ilmu orang-orang Islam dipindahkan melalui buku-buku mereka yang telah diterjemahkan ke dalam bahasa Eropa. Buku- 
buku itu mencakup sain yang dipelajari di universitas-universitas Eropa dan berlangsung dalam jangka waktu lima abad. Begitulah buku-buku Ibn Rusyd telah menjadi asas reformasi pemikiran pada berbagai universitas di Prancis sejak abad ke 13.22 Jadi jelas kemasyhuran Ibn Rusyd di Barat disebabkan pemikiran-pemikiran serta buku-buku karangannya dalam bidang filsafat. Gelar yang diterimanya sebagai komentator adalah dari hasil terjemahan dan penafsirannya terhadap buku filsafat karangan Aristoteles. ${ }^{23}$

Secara garis besar dapat disimpulkan bahwa aliran filsafat Ibn Rusyd sangat rasional. Ia menjunjung tinggi akal fikiran dan menghargai peranan akal, karena dengan akal pikiran itulah manusia dapat menafsirkan alam wujud. Akal pikiran bekerja sama atas dasar pengertian umum (ma`ani al-kulliyyah), di dalamnya tercakup semua hal yang bersifat khusus (juziyyah). Pada abad pertengahan orang memperdebatkan soal kulliyat, apakah hanya nama belaka ? atau mempunyai wujud nyata di luar akal atau hanya merupakan gambaran akal semata-mata. Dengan terus terang ia mengatakan bahwa kulliyat adalah gambaran akal dan tidak berwujud sebagai kenyataan di luar akal.24

Seorang filosof yang berpegang pada aliran rasional akan berkeyakinan bahwa segala sesuatu tidak mungkin lepas dari sebab dan musabab. Keyakinan pada hukum sebab dan musabab ini adalah asas ilmu pengetahuan alam dan falsafah rasional. Sebagai seorang yang berfikir rasional Ibn Rusyd menafsirkan ajaran agama dengan penafsiran rasional, namun ia tetap berpegang pada alQuran sebagai sumber agama. Jadi yang menarik dari pemikiran Ibn Rusyd itu adalah sifat rasionalnya. Karena diterimanya pemikiran Ibn Rusyd di Eropa maka ia dianggap sebagai buku rasional pertama yang telah membukakan cara berfikir merdeka di Eropa. Cara berpikir inilah yang lambat laun membawa kemajuan pesat bagi Eropa.

Walaupun Averoisme itu dilarang Gereja, tetapi pengikut-pengikutnya tidak habis-habisnya. Bahkan pada awal abad ke 14 suara Ibn Rusyd nyaring terdengar di Paris tatkala Johanes dari Jandun menyatakan gerakan Averoisme gerakan ekstrim. Dikatakan bahwa Averroisme itu adalah benar di samping kitab suci pun juga benar. Baginya ada dua macam kebenaran yaitu kebenaran filosofis dan kebenaran teologis. ${ }^{25}$

Karena hebatnya pengaruh Ibn Rusyd, pihak Gereja mengambil perhatian yang sangat besar terhadapnya. Tindakan Gereja bukan hanya sekedar melarang membaca buku-buku Aristoteles dan buku-buku Ibn Rusyd, bahkan Ibn Rusyd sendiri dianggap ateis. Oleh sebab itu Paus memerintahkan untuk memburu dan membunuh orang-orang yang dianggap murtad. Romenas, seorang ahli ilmu pengetahuan dipenjara sampai meninggal dan mayatnya dibakar hanya karena ungkapan bahwa "pelangi adalah sinar matahari ke atas air" bukan seperti kepercayaan yang mengatakan "pelangi diciptakan Tuhan untuk menyerang hamba-hambanya yang keluar dari ajaran agama. ${ }^{26}$

Begitulah perjuangan sengit yang terjadi di Eropa antara kelompok Geraja dan kelompok Avrroisme yang berpangkal dari pemikiran rasional Ibn Rusyd. Walaupun pihak musuh Averroisme mencoba menghalangi masuknya pemikiran rasional ke Eropa, namun gerakan tersebut mendapat tempat dalam masyarakat Eropa pada abad-abad berikutnya. 
Ada lima faktor yang menyebabkan Averoisme subur di Eropa pada abad pertengahan : Menurut MM Syarif "No Moslem thinker influenced the medieval west more than Ibn Rusyd". Averoisme telah menimbulkan banyak pengikut dan sekaligus penentangnya disebabkan penafsiran alegoris terhadap kitab suci, teori dua kebenaran, pan-psikisme yang mengatakan immortalitas jiwa individu, keabadian dan potensialitas materi dan emansipasi wanita.

Sebagaimana diketahui banyak orang, Averoisme adalah pembela gigih ta`wil dalam menafsirkan al-Quran. Dengan mengikuti ayat al-Quran 3:5 Ibn Rusyd mempertahankan hak orang yang berpengetahuan luas untuk mengetahui ta`wil. Yang dimaksud dengan orang yang berpengatahuan luas adalah filosof. Bila Aristoteles menyebut empat macam argumen sofistik, didaktik, dealektik, exemination, dan contentious, Ibn Rusya menyebut tiga saja, yaitu demonstratif, dealektis dan retoris. Argumen demonstratif dipakai filosof, argumen dealektis digunakan mutakallimun, dan argumen retoris digunakan orang-orang awam. Al-Quran kata Ibn Rusyd ditujukan kepada seluruh manusia dan karena itu al-Quran menggunakan tiga metode itu sekaligus. Takwil atau penafsiran alegoris ini kelak menimbulkan perdebatan sengit antara kaum skolastik dan lawan-lawannya di Eropa.

Teori dua kebenaran yang tidak diuraikan di sini adalah upaya Ibn Rusyd untuk memadukan reason dan revelation. Masih menurut M. M Syarif (1966:1380) : Ibn Rusyd's theory of two truth combined with the doctrine that matter is eternal and potent to produce all forms from within itselsf, was a good-send for the scientifically-minded people in the West who were as a rule, condemned and persecute by the orthodox Church and state. The found in the obey theses, which passed as Averoism, their best support. For this reason, de Wulf calls Ibn Rusyd Doctor of the AntiScholastics.

Kesetiaan dan dukungan orang-orang Yahudi sangat berpengaruh untuk mempopulerkan Averoisme di Eropa. Ketika Abu Yusuf, Ya`qub al-Mansur mengusir Ibn Rushd dari Maroko, orang-orang Yahudi juga dikejar-kejar. Mereka pindah ke negara-negara tetangga, misalnya Leon, Castile, Perancis (dengan menyeberangi Pyranea), dan ke Sicilia. Mereka disambut oleh Alfonso VI yang mempercepat perkenalan orang-orang Kristen pada karya-karya Islam. Putra-putra Alfonso Ferdinand II dan Alfonso melanjutkan tradisi ini. Keluarga Tibboni misalnya secara khusus menerjemahkan karya-karya Ibn Rushd di Lunel. Di samping para sarjananya, para pedagang dan negarawan Yahudi juga menyebarkan Averoisme, terutama sekali the Friars. Berkat orang Yahudi juga Averoisme pernah bertahta di Paris ketika Thomas Aquinas pindah dari Itali ke Paris, ia jengkel melihat popularitas Averois di sana. Williem Aufergne mengatakan bahwa banyak orang di Universitas menelan Averoisme mentah,mentah. Ketika Thomas mengajar di Paris (1252-1261) gerakan Averois tengah mencapai puncak kejayaannya. Siger de Braband membela mati-matian Ibn Rusyd dan mengancam Albertus Magnus (yang menulis On the Unity of Intelect again Averoes) dan Thomas Aquinas. Ia memperoleh banyak dukungan, walaupun gagal menjadi rector universitas.

Di kalangan penguasa, Thomas Aquinas yang menang. Tahun 1264 Bishop Paris Irlenne. Templer mengeluarkan kutukan dan membid'ahkan (memindahkan) 13 proposisi Averoisme. Tahun 1377 Siger de Braband diadili 
inkuisisi dan mengakhiri hidupnya di penjaran Roman Curia dibunuh di Orvieto oleh pembunuh setengah gila. Orang Yahudi membawa Averoisme ke universitas-universitas dan sekaligus membawa bencana.

Tahun 612 Fredrik II menjadi Kaisar Roma. Ia terdidik di Palermo, berguru kepada orang-orang Arab, berhubungan dengan orang-orang Islam di Sicilia dan selama perang Salib dengan orang-orang Syria. Ia menjadi pengagum Ibn Rusyd. Ia memerintahkan Michael Scott menerjemahkan karya-karyanya dan menyebarkannya di lingkungan ilmiah di Eropa.

Fredrick II terkenal karena sikapnya yang ramah pada orang-orang Islam. Di Fruili secara mencolok ia menghadiri perayaan umat Islam. Its was said by his rivals, menurut laporang Matthew Faris, that the Emperor agreed and believe in the law of Mohammad more than that of Yesus Christ... and was more friends to the saraceus than to the Christians.

Faktor terakhir yang menyebabkan popularitas Averoisme di Eropa adalah ikatan yang erat antara Ibn Rushd dengan Aristoteles. Orang-orang yang ingin mempelajari Aristoteles, terutama pada masa renaissance - tidak bisa tidak harus melewati Averoisme. Dante Alligieri walaupun sangat fanatik menempatkan Averois pada tempat yang istimewa di Neraka di samping Avecina dan Galen. Ia menyebutnya Averois cha"l gran conmento, Averois pensyarah besar. Kadang-kadang orang-orang yamg mau mengkritik Averoime menggunakan metode Averois. Thomas Aquinas misalnya ia mengkritik Averoisme sembari menggunakan metode sharh Averois dalam menafsirkan Aristoteles, menerima penafsiran alegoris, memakai kritik Averois untuk menyerang mistisisme. Musuh Averoisme hanya menjadi musuh yang tangguh dengan menjadi Averrois.

Periode renaisance yang mendapat pengaruh dari gerakan Averroisme di Eropa antara lain, zaman kebangkitan kembali (renaisance) kebudayaan Yunani pada abad ke 14 yang mula-mula di Italia, kemudian menyebar ke seluruh Eropa, zaman gerakan pembaharuan agama Kristen yang bermula pada abad ke $8 \mathrm{M}$ dan memuncak pada abad ke $16 \mathrm{M}$ dengan Martin Luther dan Calvin yang tampil sebagai revormatornya. Zaman Humanisme dan rasionalisme pada abad ke 17 yang dikembangkan oleh Rene Descartes, John Locke dan lain-lain, zaman Pencerahan pada abad ke 18 dengan Voltaire, Baron de Montesquieu dan Leibniz sebagai tokoh-tokohnya. ${ }^{27}$

Dari tahun 1495 - 1509 di Toledo mengajar seorang professor yang disebut Durant (1453-1534) sebagai the microscopic bombshel or renaissance philopihy. Sambil mengakui tetap sebagai Kristen yang taat Pomponazi menolak doktindoktrin gereja. Sebagai pemeluk agama katanya ia menerima malaikat dan roh, sebagai filosof tidak. Sabagai filosof katanya lagi ia melihat agama Kristen adalah agama yang sedang mati. Filsafat sebaliknya sedang muncul sebagai puncak kebenaran. Hanya saja rahasia filsafat sebaiknya tidak diajarkan kepada orang awam. "We must beware even of holding discource concerning them with ignorant priest" kata Pomponazzi.

Pomponazzi memasukkan skeptisisme ke Italia sehingga pada abad ke 15 dan 16 orang Itali menjadi orang Eropa yang paling skeptis. Kaum agama jelas marah sekali. Lalu siapa yang dituding sebagai biang keladinya kerusakan pikiran Pomponazzi. Vanini, pegagum Pomponazzi menjawab, Phitagoras would 
have judge that the soul of Averous has transmigrated into the body of Pomponazzi. Jadi kalau diurut ke belakang, renaissance tumbuh subur karena dorongan skeptisisme yang berkembang karena dorongan Averoisme. Renaisance adalah merupakan puncak Averoisme dalam pemikiran Barat.

Seperti yang telah diterangkan di atas masyarakt telah terbagi kepada dua kelompok. Satu kelompok meyokong pemikiran Ibn Rusyd dan yang satu lagi menentangnya. Dengan demikian, timbul pro dan kontra dalam masyarakat Eropa disebabkan oleh pemikiran Ibn Rusyd yang rasional.

Di dunia Barat Ibn Rusyd lebih dikenal dengan nama Averoes. Adapun titik tolak semangat dan pengaruh serta refleksi pemikiran falsafatnya sangat populer dengan sebutan Averoisme. Ciri utama filsafat Aristoteles yang diserap dan kemudian dipantulkan kembali oleh Ibn Rusyd serta diterima oleh pemikirpemikir Barat ialah argument-argumen logis yang membuka jalan bagi pemikiran rasional. ${ }^{28}$

\section{Pengaruh Averois terhadap perkembangan dunia Moderen.}

Adalah tidak mudah untuk menentukan pengaruh seorang pemikir masa lalu bagi kemajuan peradaban manusia sebesar apapun ketokohan pemikir tersebut. Kesulitan terutama adalah untuk menentukan manakah di antara unsure-unsur kehidupan manusia yang langsung dipengaruhi oleh hasil karia pemikir tersebut. Lain halnya dengan penemu ilmiah, baik penemuan teoretis maupun penemuan terapan. Kelihatan lebih mudah mengukur karya seorang penemu seperti Thomas Alva Edison dalam bidang (penemu listrik), atau Albert Enstein dalam bidang relativitas massa dan energi karena hasil temuan mereka langsung dapat dijumpai dan ditunjukkan dalam kehidupan. Lain halnya dengan temuan Plato tentang masyarakat, temuan Aristoteles tentang sebab dan sebagainya.

Pengaruh lain kelihatan dari karya-karya selain Bidayah al-Mujtahid adalah karyanya dalam bidang kedokteran dan sastra. Prestasinya di bidang kedokteran cukup membuktikan ketangguhan ilmiahnya karena teori-teorinya tentang optik dan penyakit menular merupakan temuan-temuan baru pada masa itu. Petunjuk kepada pencegahan penyakit melalui vaksinasi yang baru bebrapa abad kemudian dapat ditemukan cara ilmiah untuk mewujudkan hasil pengamatannya itu. Karya utamanya di bidang kedokteran terdiri atas tujuh jilid meliputi semua bidang kedokteran yang dikenal waktu itu dan menjadi buku standar kedokteran beberapa abad lamanya.

Namun kecemerlangannya yang tertinggi adalah filsafat yang sekaligus mengukir namanya dalam sejarah. Oleh penulis-penulis filsafat ia dijuluki sebagai filosof muslim terbesar. Ia memang lahid dan berkiprah di Andalusia Afrika Utara, ujung Barat Dunia Islam. Penelusuran terhadap Ibn Rusyd yang memungkinkan adalah bidang filsafat. Dante menyebutnya sebagai The Comentator (sang Pensyarah) karena jasa Averroes yang tidak ternilai dalam menampilkan kembali kemurnian filsafat Aristoteles, setelah beberapa abad bercampur aduk dengan pendapat Plotinus dan paham-paham lain yang mengaburkan pendapat Aristoteles itu. 
Averroes menemukan patronase dari Amir Ya`qub a-Mansur di Seville, dan dari penguasa itu ia memperoleh tugas-tugas keilmuan yang akhirnya memunculkan kebesaran Averroes sendiri. Setelah menyelesaikan tugas menulis buku dan ensiklopedi Kitab Kulliyah fi al-Tib sebanyak tujuh jilid dan komentar atas puisi kedokteran Arjuzah fi al-Tib karya Aviccena (Ibn Sina) serta kitab.

Di sisi lain yang menyebabkan Averroisme diterima di Barat adalah pemikriannya tentang pertemuan filsafat dan agama. Di Barat yang menentukan adalah gereja. Sesuatu yang bertentangan dengan gereja adalah keliru dan tidak dapat ditolerir. Oleh sebab itu, antara ilmu pengetahuan dan agama bukan bertolak belakang dan bukan tidak bisa dipertemukan. Dalam Islam antara filsafat dan agama dapat bertemu dan saling mendukung.

\section{Kesimpulan}

Perjalanan Averoisme ke Eropa tidak terlepas dari dua pengaruh besar, yaitu pengaruh dari dalam negeri Islam sendiri dan pengeruh di luar Islam. Nama Averoisme mencuat setelah mendapat kritik dari para ahli fikih yang menuding bahwa Ibn Rusyd telah sesat. Pengaruh luar adalah sambutan luar biasa dari mahasiswa Eropa terhadap pemikiran Averoisme yang cemerlang. Ini sejalan dengan pengusiran orang-orang Yahudi yang dilakukan oleh Khalifah alMansur.

Perjalanan Averoisme ke Eropa telah membawa pengaruh besar bagi kemajuan dunia Barat. Ide-idenya telah membuka cakrawala pemikiran orangorang Eropa dan membawa kesadaran akan ketertinggalan mereka sehingga semua itu juga mendorong mereka untuk mempersiapkan langkah-langkah untuk pengembangan ilmu pengetahuan. Pemikiran rasional Averoisme ini terrealisasi dengan penemuan baru yang mengubah wajah Barat menjadi penguasa teknologi.

\section{Catatan Akhir:}

1Telah menjadi kenyataan bahwa nama para filosof Muslim yang sangat berpengaruh bagi pengembangan pemikiran rasional oleh pemikir Barat selalu dipakai kata yang bersifat Barat centris. Tetapi ini khusus pada filosof yang lahir di Andalusia. Pemakaian ini mungkin bermacammacam. Di antaranya adalah rasa kebanggaan untuk memiliki pemikir yang terdapat di kalangan pemikir Barat bahwa Ibn Rusyd itu berkebangsaan Eropa. 381.

${ }^{2}$ Hana al-Fakhury, Tarikh al-Falsafah al-Arabiyyah, Bairut : Dar al-Ma'arif, tanpa tahun, hlm.

${ }^{3}$ Mahmud Qasim, al-Falsafah Ibn Rusyd wa Tatawwuruha fi al-Tafkir al-Garbi, Sudan, Jama`ah Ummi Durman, 1967, hlm. 12.

${ }^{4}$ Ibid.

${ }^{5}$ Ibid., hlm 11.

6Ernest Renan, Averoes Et Laveroesme, Paris : 1852, hlm. 191.

7Mahmud Qasim, op. cit., hlm. 12-13.

8Ernest Renan, op. cit., hlm. 192.

${ }^{9}$ Muhammad Lutfi Jumah, Tarikh Falsafah al-Islam fi al-Masyriq wa al-Magrib, Kairo Maktabah al-Ma`arif, 1927, hlm. 113-114.

${ }^{10}$ Hana al-Fakhuri, Tarikh al-Falsafah al-Arabiyyah, Bairut : Maktabah al-Basilah, 1958, Jilid II, hlm, 385 . 
Al-Fikra: Jurnal Ilmiah Keislaman, Vol. 4, No. 2, Juli-Desember 2005

11Zakaria, Hasyim Zakaria, Fadhl al-Hadarat al-Islamiyah wa al-Arabiyah `ala al-Islami, Kairo : Dar al-Nahdah al-Fajjalah. 1970, hlm. 361.

12Zainal Abidin Ahmad, Riwayat Hidup Ibn Rusyd, Jakarta: Bulan Bintang, 1975, hlm. 144.

13Zakaria Hasyim, op. cit., hlm. 306.

${ }^{14}$ Mahmud Qasim, op. cit., hlm. 18.

${ }^{15}$ Ibid., hlm. 26.

16Zainal Abidin Ahmad, op. cit., hlm. 148.

17Hasibullah Bakri, Di Sekitar Scholastik Islam, Jakarta: Tinta Mas, 1973, hlm. 85.

18Mahmud Qasim, op. cit., hlm. 14.

19Ibid., hlm. 14-15.

20Siger de Van Braban dikatakan sebagai murid Ibn Rusyd kerena pendapatnya yang menyokong pendapat Ibn Rusyd.

${ }^{21}$ Muhammad Yusuf Musa Thomas Aquinas digelari sebagai al-Gazali al-Masihiyyah, lihat Muhammad Yusuf Musa, Bain, hlm. 15.

22Zakaria Hasyim, op. cit., hlm. 384.

23Harun Nasution, op. cit., hlm. 48. Lihat juga Zainal Abidin Ahma, op. cit., hlm. 130.

${ }^{24} \mathrm{Ahmad}$ Fu'ad alAhwani, op. cit., hlm. 106.

${ }^{25}$ Hana al-Fakhuri, op. cit., hlm. 392.

26Zakaria Hasyim, op. cit., hlm. 332.

${ }^{27}$ Claude Delmas, Tarikh al-Hadharah al-Arabiyyah, Bairut : Dar al-Masnyurat, 1970, hlm. 54, 60, 69. Lihat juga Poeradisastra, Sumbangan Islam kepada Ilmu Pengetahuan Moderen, Jakarta : PBM, 1986, hlm. 77.

28Poul Edwards, (Ed.), The Encyclopaedia of Philosophy. New York, Macmillan Press, Jilid I, 1976, hlm. 224. 